\author{
Doc. dr. sc. Nina Mišić Radanović ${ }^{1}$ \\ Sveučilišni odjel za forenzične znanosti Sveučilišta u Splitu
}

\title{
POVIJEST PRAVNE ODGOVORNOSTI LIJEČNIKA
}

UDK: 347.56:614.25 (091)

DOI: $10.31141 /$ zrpfs.2020.57.137.783

Izvorni znanstveni rad

Primljeno:15. II. 2020.

\begin{abstract}
Današnje uređenje pravne odgovornosti liječnika, ali i drugih medicinskih djelatnika ne može se razumijeti bez uvida u povijest razvitka te vrste profesionalne odgovornosti. Autorica prikazuje uređenje odgovornosti liječnika u pravnim dokumentima starog vijeka, uključujući mezopotamijske i egipatske izvore te dokumente iz antičke Grčke i rimskog prava. Također, rad analizira pravno uređenje liječničke odgovornosti u srednjovjekovnom pravu kao i razvitak te odgovornosti nakon Francuske revolucije. Autorica posebno prikazuje užasnu zlouporabu liječnika i njihovu odgovornost za nacističke zločine. Zaključno, ukazuje da u suvremenim društvima sustav profesionalne pravne odgovornosti liječnika predstavlja srednji put između dviju krajnosti.
\end{abstract}

Ključne riječi: odgovornost liječnika, antički dokumenti, pravni izvori rimskog prava, srednjovjekovno pravo, odgovornost u novom vijeku

Moderna legislativa i judikatura pravne odgovornosti liječnika ne može se razumijeti bez spoznaja o njenom povijesnom razvitku. S obzirom na to da je medicinska profesija jedna od najstarijih profesija, povijest od najranijih društava pokazuje snažnu povezanost prava i medicine upravo u pitanju odgovornosti. Duga evolucija pravne odgovornosti liječnika seže od davne prošlosti kada je medicina bila magija i mistika, a liječnici čarobnjaci s natprirodnim moćima te je njihova odgovornost zbog smrti pacijenta bila bezuvjetna.

1 Doc. dr. sc. Nina Mišić Radanović, docentica na Katedri za pravne znanosti u forenzici Sveučilišnog odjela za forenzične znanosti Sveučilišta u Splitu (Assistant Professor, Chair of law sciences in forensic, University Department of Forensic Sciences, University of Split,): nina.misic.radanovic@unist.hr. 


\section{ODGOVORNOST LIJEČNIKA U PRAVNIM DOKUMENTIMA STAROGA VIJEKA}

Premda se pravni tekstovi iz antičkog vijeka nisu posebno bavili odgovornošću u području medicine, uređenje pravne odgovornosti odnosi se, ipak, i na različite aspekte rada liječnika. Iako se u antičkom svijetu uloga liječnika izvodila iz mitske tradicije o liječniku bogu, ${ }^{2}$ poziv liječnika smatrao se profesijom od posebnog društvenog interesa, zbog čega je društvo moglo i sankcionirati njegovu nestručnost. Prva pisana pravila o građanskoj i kaznenoj odgovornosti liječnika nalaze se u najstarijem pravnom dokumentu drevne Mezopotamije Hamurabijevom zakoniku koji propisuje stroge sankcije za liječnike koji su nanijeli štetu zdravlju pacijenta. Mezopotamijski liječnici smatrali su se odgovornima samo za kirurške pogreške i propuste, jer je zakonik spominjao izrijekom određene odgovornosti u vezi s operacijom ili „uporabom noža“ (,bronze lancet"). Iz toga proizlazi da liječnici nisu bili odgovorni za bilo koje nekirurške greške ili neuspjele pokušaje izlječenja bolesti. Međutim, njihova odgovornost ovisila je o društvenom statusu pacijenta odnosno njegovoj klasnoj pripadnosti te je zbog nepropisnog postupanja prema pacijentu koji je imao status slobodnog građanina liječnik odgovarao strože nego zbog istog takvog postupka prema pacijentu koji je bio rob: "Ako liječnik brončanim nožem nekome nanese tešku ranu i ubije ga ili nekome otvori oko i uništi oko, neka mu se odsiječe ruka“ ${ }^{4}$ U slučaju da je liječnik zadao tešku ranu i ubio roba, obeštetit će vlasnika roba novim robom, a ako mu je brončanim nožem otvorio oko i uništio ga, mora platiti pola vrijednosti roba. ${ }^{5}$ Zanimljivost je Hamurabijevog zakonika da u različitim slučajevima spominje odgovornost osoba koje su nemarne u obavljanju svog zanimanja, među ostalim, vrtlara, brijača, pastira, gostioničara, pa čak i graditelja. ${ }^{6}$

2 O mitu "physician-hero/physician-god” v. Francis, K. C., „Medical ethos and social responsibility in clinical medicine", Journal of Urban Health: Bulletin of the New York Academy of Medicine, vol. 78, 1, March 2001, str. 30.

3 Zakonik naroda Staroga istoka koji je babilonski kralj Hamurabi (1792. - 1750. g. pr. Kr.) dao uklesati na kamenu stelu visine 2,62 $\mathrm{m}$ i objaviti narodu negdje pri kraju svoje vladavine. Na vrhu stele prikazan je kralj kako stoji pred bogom Šamašom, zaštitnikom pravde. Zakonik sadrži 282 propisa od kojih dio nije sačuvan u cijelosti. Izvor: www.starapovijest.eu/hamurabijev-zakonik.

4 Riječ je o talionskom načelu kažnjavanja ili tzv. odraznom talionu kao kazni koja pogađa onaj dio tijela kojom je povreda nanesena, čime je liječnik gubio svoju sposobnost da ostane praktičar. Osim zadovoljštine pružene oštećenom pacijentu, time je istovremeno ostvarivana i preventivna svrha, jer taj liječnik ubuduće više nikoga ne može povrijediti. Cit. Zietsman, C. J., Medical Negligence In Ancient Legal Codes, str. 95. Dostupno na: http://akroterion.journals.ac.za.

5 Također, propisane su naknade ili nagrade liječniku za uspješne operativne zahvate te, opet ovisno o klasnom položaju, nagrada iznosi deset šekela srebra za plemića, pet šekela za siromaha (muškenum) i dva šekela koji plaća vlasnik za roba. Cit. Swanepoel, M., „,The Development of the Interface between Law, Medicine and Psychiatry: Medico-Legal Perspectives in History“, Potchefstroom Electronic Law Journal. 2009; 12 (4), str. 140. Dostupno na: https://doaj.org/article/0e4ec424a402434.

6 Zietsman, C. J., op. cit., str. 93. 
U starom Egiptu liječnici, koji su uživali veliki ugled, ${ }^{7}$ morali su se strogo pridržavati pravila i nisu bili izuzeti od odgovornosti za nesavjesno obavljanje svoje djelatnosti. Upozoravalo ih se da primjenjuju pravila i metode sadržane u drevnim svetim spisima, jer će samo tako biti besprijekorni. Ako je liječnik obavljao liječenje u skladu s tim pravilima, bio bi oslobođen odgovornosti i u slučaju da je bolesnik umro odnosno liječenje bilo neuspješno. Međutim, ako je odstupio od tih tradicionalnih pravila i lijekova, pokušavajući povećati svoje znanje kroz eksperimentiranje, liječnik je preuzimao punu odgovornost i mogao je biti kažnjen i smrtnom kaznom zbog neuspjelog liječenja. ${ }^{8}$ Time se očiglednim pokazuje činjenica da pružanje pravne zaštite pozivanjem na "prevladavajuće (općeprihvaćene) medicinske standarde" stoji kako u pozadini moderne tako i drevne medicinske prakse. Istovremeno, u antičkoj Grčkoj liječnik je bio oslobođen kažnjavanja ako je bolesnik umro "protivno volji onoga koji ga je liječio". ${ }^{9}$ Stari Grci nisu poznavali zakonske mehanizme kojima je pacijent koji je pretrpio štetu, ili njegovi rođaci ako je umro, dok je bio pod liječničkom skrbi mogao zatražiti pravnu zadovoljštinu. Smatrali su da je medicina najistaknutija od svih umjetnosti, ali zbog neznanja onih koji je prakticiraju i onih koji brzopleto sude svoje praktičare, ona daleko zaostaje za svim drugim umjetnostima. Glavnim uzrokom činila se činjenica da samo za medicinu, osim loše reputacije odnosno ugleda, nije određena kazna: "Samo liječnici i odvjetnici mogu počiniti ubojstvo a da ne odgovaraju za njega". ${ }^{10} \mathrm{~S}$ obzirom na nepostojanje zakona koji bi kaznili nestručnost, samo je liječnik mogao počiniti nekažnjeno ubojstvo te je ovaj nedostatak kažnjavanja za nesavjesno liječenje u antičkoj Grčkoj značajna razlika u odnosu na profesionalnu odgovornost danas.

Prema propisima rimskog prava, ${ }^{11}$ liječnik je odgovarao za smrt bolesnika, ali samo ako je do smrti došlo zbog stručne greške, pri čemu se smatralo da je neprimjerenost ili nestručnost izjednačena s nemarnošću. Drugim riječima, već je u rimskom pravu uvjet za uspostavljanje odgovornosti liječnika za smrt pacijenta bila liječnička pogreška, a nestručnost liječnika odgovarala je njegovoj krivnji (imperitia

7 U Egiptu liječništvom su se bavili svećenici i laici školovani liječnici od kojih su neki bili posebno školovani, čak specijalisti, na dužnosti kod faraona. Među ovim posljednjim bio je Imhotep koji je kao visoki činovnik obnašao dužnost bilježnika i arhitekta, visokog svećenika i liječnika vladara III. dinastije Djosera. Izvor: https://www.britannica.com/biography.

8 Swanepoel, M., op . cit., str. 137. Isto Joffe, A., Egypat and Syromesopotamima in the 4th Milenium: Implicate of the New Cronology, 2000.

9 Aleksandar Makedonski razapeo je liječnika Glauka, jer je tijekom liječenja Aleksandrovog prijatelja otišao nemarno u kazalište, a bolesnik je umro. Šeparović, Z., „Život doveden na rub“, Rev. za soc., Zgb., Vol XXI (1990.), No 2, str. 300.

10 Cit. prema Swanepoel, M., op. cit., str. 146. Grmek navodi da su upravo zbog mogućih smrtnih ishoda neki od grčkih autora, npr. Antifont i Filemon, govorili o liječniku kao o nekažnjivom ubojici. Cit. prema Štojs, T., „Istraživanja na ljudskim subjektima - povijesni razvoj, načela i primjeri neetičnih postupanja“, Nova prisutnost 12 (2014.) 1, str. 95.

11 „In the Roman Empire the first by-laws incriminating the doctor responsibility are the Lex Cornelia and Lex Aquilia. “ Cit. Badjakova, V., ,The Responsibility of The Healthcare Workers Shown Through The Prism of The Judicial Practise“, Iustinianus Primus Law Review, vol. VI, br. 2, 2015., str. 2. 
culpae adnumeratur - neznanje liječnika rađa krivnju $)^{12}$ tj. liječničko neznanje i nesposobnost smatrana je nemarnošću ili culpom. ${ }^{13}$ Ovo se pravilo primjenjivalo u slučajevima u kojima je liječnik obavljao operacije na nekvalificirani način te kada je liječnik propisao za pacijenta pogrešan lijek pa je bio odgovoran zbog znanja da njegovo neiskustvo ili nesposobnost može biti opasno za druge osobe. Dakle, široko postavljen pojam "liječničke pogreške" obuhvaćao je neiskustvo, neopreznost i neukazivanje medicinske pomoći te je liječnik bio odgovoran za operaciju obavljenu protivno pravilima medicinske vještine, ${ }^{14}$ zbog nepravilne uporabe lijekova, čak i za operaciju izvedenu lege artis, ali je kasnije pacijenta nemarno liječio. Rimsko pravo je dopuštalo mogućnost da bolesnik umre usljed težine same bolesti, međutim, za namjerno ubojstvo, za prodaju otrova kojim kupac želi otrovati nekoga te za pobačaj i kastriranje, liječnici su kažnjavani jednako kao i ostali rimski građani. Shodno tome, liječnička pogreška povlačila je imovinsku odgovornost, jer je liječnik za smrt roba imovinski odgovarao njegovom gospodaru. Premda se antički pravni tekstovi nisu bavili medicinskim pitanjima kao takvima, izraz „medicinska nepažnja“ pojavljuje se u rimskom pravu u nekoliko tekstova. Tako se dva teksta odnose na propisivanje lijekova, u kojima je Ulpijan opisao situaciju u kojoj primalja daje lijek ženi koja potom umire zbog djelovanja lijeka: ako osoba, uporabom sile ili uvjeravanja, daje lijek drugoj osobi, bilo oralno ili intravenozno, ili kao otrov, ona je odgovorna prema Lex Aquilia za štetu, baš kao i primalja koja osobno daje lijek zbog čijeg je djelovanja žena umrla. ${ }^{15}$ Dva se teksta bave pitanjima liječničke dužne pažnje, pa Proculus kaže da ako liječnik neznalački (imperite) liječi roba, na njegovu se radnju primjenjuje ugovorna odgovornost (ex locato) ili Lex Aquilia dok Gaius dodaje da isto vrijedi i ako liječnik nepropisno primjenjuje lijek kao i ako liječnik ispravno liječi, a potom napusti liječenje, kriv je za culpu. Ulpijan tvrdi da su liječnici odgovorni in factum za nesavjestan odnos bilo koje vrste. Bez obzira na to smatra li se liječnik odgovornim jer je liječnik ili zbog toga što pruža medicinske usluge, njegov je nehaj imperitia ili nedostatak vještine/ znanja, a koji Justinijan smatra nemarom u smislu Lex Aquilia. ${ }^{16}$

12 Digest: Ad Legem Aquiliam 501732 “(Gaius 7 Ad Edictuum Provinciale): Imperitia Culpae Adnumeratur"; Inst Just 43 7: "Imperitia culpae adnumeratur, veluti si medicus ideo servum tuum occiderit, quod eum male secuerit aut perperam ei medicamentum dederit" D 9278 "(Ulpianus 18 Ad Edictum) Proculus ait, si medicus servum iperite secuerit vel ex locato vel exlege Aquilia competere actionem”; D 9278 “(Gaius 7 Ad Edictum Provinciale): Idem iuris est si medicamento perperam usus fuerit”. Cit. Swanepoel, M., op. cit., str. 148.

13 Rimsko pravo razvilo je razlikovanje između dolusa, culpe \{uključujući i nemar (negligentia) i nesposobnost (imperitia) i casusa (nezgode, slučaja)\}, s time da je dolus namjerno djelovanje (malice, evil intent), za razliku od culpe i casusa. Cit. ibid.

14 U rimskom pravu u slučajevima medicinske nepažnje teret dokazivanja bio je na tužitelju koji je morao dokazati da je navodni nemar od strane liječnika prouzročio tjelesne ozljede. Primjena pravila rimskog prava imperitia culpae adnumeratur našla je svoje mjesto i u nizozemskom pravu u kojemu su pojmovi onwetenheid, onverstand i zwackheid, u kontekstu pravne odgovornosti, izjednačeni s pojmom krivnje. Ibid., str. 149.

15 Cit. Zietsman, C. J., op. cit., str. 91.

16 „A doctor is liable in medical terms if he operates unskillfully, and also legally especially if he fails to follow up on the operation, that is, if he fails to do something. " Cit. ibid., str. 92. 
Iz navedenog su očigledna dva zaključka, prvi, da je liječničku djelatnost već u antičkom Rimu uređivala sama država ${ }^{17}$ te, drugi, da se od tada do danas postupno uobličavala pravna odgovornost liječnika u slučaju pogreške. U rimskom pravu veliki je pomak napravljen u smislu prihvaćanja da smrt pacijenta može biti i posljedica teške bolesti, a ne samo pogreške liječnika. Liječnička odgovornost zbog neiskustva, neznanja, neopreznosti ili nepružanja pomoći nije bila apsolutna kao što je to bilo u ranijem razdoblju nego je trebalo dokazati uzročno-posljedičnu vezu liječničke pogreške i posljedice. Upravo ovakav razvoj postao je ključan za oblikovanje modernog uređenja odgovornosti liječnika. ${ }^{18}$

Prema Corpus Iuris Canonici, najznačajnijem izvoru kanonskog prava Katoličke crkve, liječnici koji pri propisivanju lijekova krše zapovijedi Dekaloga krivi su za smrtni grijeh, kao i u slučaju da su eksperimentirali na bolesnoj osobi s nepoznatim lijekovima (osim ako su sve nade za ozdravljenje bile izgubljene te je to bila posljednja mogućnost). Također, liječnici se upozoravaju da će smrtno zgriješiti ako je njihov pokušaj liječenja teške bolesti, a da pritom nisu postupali u nuždi, uzrokom teške štete za pacijenta zbog njihova skrivljenog neznanja ili neiskustva. ${ }^{19} \mathrm{U}$ doba ranog kršćanstva, neuspjelo liječenje je strogo kažnjavano, pa je tako u Palestini, zbog nepružanja medicinske pomoći ljudima slobodnih zvanja, liječnika očekivala sramna smrt i konfiskacija imovine, a ruku su mu odsijecali zbog tjelesne ozljede bolesnika prouzročene neuspjelom operacijom. ${ }^{20}$

Najstarija pravila etičkog postupanja liječnika nalaze se već u tekstovima koji potječu od starih Egipćana, Kineza, Perzijanaca dok su u antičkoj Grčkoj izražena u tekstu liječničke zakletve kako ju je formulirao liječnik i filozof Hipokrat. Dakle, najstarija kodifikacija liječničke etike jest Hipokratova zakletva, nastala u V. stoljeću pr. Kr. u kojoj su sadržana temeljna, i u to vrijeme važeća, deontološka načela, a polagali su je pripadnici asklepijata (liječničkih organizacija). Time je Hipokrat postavio temelje moderne medicine, oslobađajući je od religije te uvodeći znanstvena načela promatranja čovjeka i prirode. Budući da su antički filozofi shvaćali čovjeka kao psihofizički jedinstveno biće, bolest je za njih znak istodobno duševne i tjelesne poremećenosti, što je vidljivo i u Hipokratovim načelima liječničkoga djelovanja. On ističe da svoje znanje i moći na najbolji način stavlja u službu ozdravljenja bolesnih, a to ponajprije znači da će i sam pokušati spoznati psihofizičko ustrojstvo čovjeka. Ta se spoznaja, dakle, shvaća kao etička obveza, štoviše kao jedini mogući

17 Tako su jedan smrtni slučaj 931 n. e. u Bagdadu i očigledna liječnička nestručnost bili povod da se naredi i provede revizija odnosno provjera znanja svih arapskih liječnika.

18 Tako Blagojević, I., „Priznanje prava na naknadu štete povodom neželjenog rođenja deteta u američkom pravu i osiguranje lekara i pacijenata“, Evropska revija za pravo osiguranja, 4, 2013., str. 59. Dostupno na: scindeks-clanci.ceon.rs/data/pdf/2334...

19 Clark, M., Crawford, C., Legal Medicine in History, cit. prema Swanepoel, M., op. cit., str. 150.

20 Nenadović, M., Medicinska etika, Beograd, 2007. 
način liječničkoga djelovanja ${ }^{21}$ te je tako nastala izvorna zakletva koju su polagali svi liječnici koji su pripadali Hipokratovom društvu Asklepiada. ${ }^{22}$

Prikaz propisa staroga vijeka o odgovornosti liječnika nametnuo je sljedeći zaključak. Iako model naknade štete odnosno obeštećenja pacijenta umjesto kažnjavanja za pogrešno liječenje u mezopotamijskom društvu nije bio toliko razvijen kao što je bio u rimskom pravu, ipak je činjenica da se oba koncepta pojavljuju u ranim pravnim propisima. Međutim, opća je značajka toga doba da je visina obeštećenja odnosno težina kazne u Mezopotamiji bila više povezana $s$ građanskim statusom odnosno klasnim položajem oštećenika nego je to bio slučaj u rimskom pravu. ${ }^{23}$ Također, opća je značajka starog mezopotamijskog društva i talionsko načelo „oko za oko, zub za zub“ ako je štetu pretrpio slobodan čovjek, dok je za štetu nanesenu robu kazna bila kompenzacijska. Međutim, temeljna pravna filozofija bila je univerzalna: šteta nastala bilo kao rezultat nepažnje, nemara, propusta i nedostatka vještine ili znanja, nije ostajala nekažnjena ni u Mezopotamiji i Egiptu ni u starom Rimu. ${ }^{24}$

Rimski model odgovornosti liječnika, s manjim ili većim izmjenama, preuzele su srednjovjekovne europske države i polisi srednjoeuropsko-sredozemnoga

21 „Kasnije će ta jedinstvena slika čovjeka pomalo blijedjeti, a upravo je ona, u različitim oblicima, uvijek bila pretpostavka vrednovanja etičke opravdanosti nekog postupka što ga čovjek čini drugome ili trpi od njega. Samo ispravno znanje o tome što je čovjek i kakvo je njegovo ontološko ustrojstvo trebalo je jamčiti i ispravno djelovanje liječnika. " Cit. Čehok , I., Filozofija i medicinska etika, Druš. istraž. Zagreb/ god. 5 (1996.), br. 3-4 (23-24), str. 600.

22 Tekst glasi: “Kunem se Apolonom liječnikom, Asklepijem; Higijejom i Panakejom, svim bogovima i božicama, zovući ih za svjedoke, da ću po svojim silama i savjesti držati ovu zakletvu i ove obveze. Stoga ću učitelja ovoga umijeća štovati kao svoje roditelje, njegovu ću djecu držati svojom braćom, a budu li htjeli učiti ovu umjetnost, puočavat ću ih bez ugovora i bez. plaće. Puštat ću da sudjeluju kod predavanja i obuke $i$ u svem ostalom znanju moja djeca i djeca moga učitelja. Učit ću $i$ đake koji se budu ugovorom obvezali i ovom zakletvom zakleli, ali nikoga drugoga. Svoje propise odredit ću po svojim silama $i$ znanju na korist bolesnika $i$ štitit ću ga od svega što bi mu moglo škoditi ili nanijeti nepravdu. Nikome neću, makar me za to i molio, dati smrtonosni otrov, niti ću mu za nj dati savjet. Isto tako neću dati ženi sredstvo za pometnuće ploda. Isto ću i pobožno živjeti i izvršavati svoju umjetnost. Neću operirati mokraćne kamence, nego ću to prepustiti onima koji se time bave. U koju god kuću stupim, radit ću na korist bolesnika, kloneći se hotimičnog oštećivanja, a osobito zavođenja žena i muškaraca, robova i slobodnih. Što po svojem poslu budem saznao ili vidio, pa i inače, u saobraćaju s ljudima, koliko se ne bude javno smjelo znati, prešutjet ću i zadržati tajnu. Budem li održao ovu zakletvu i ne budem li je prekršio, neka mi bude sretan život i ugled ljudi do u daleka vremena; prekršim li ovu zakletvu i zakunem li se krivo, neka me zadesi protivno". Izvorna se zakletva tijekom povijesti promijenila u danas prihvaćenu tzv. Ženevsku zakletvu iz 1948. godine (usvojena Ženevskom deklaracijom te dopunjena na 22. Skupštini WMA u Sydneyu 1968. godine i na 35. Skupštini u Veneciji 1983. godine) čiji je tekst: „Svečano i slobodno se zaklinjem svojom čašću da ću posvetiti svoj život služenju humanosti; da ću se s dužnim poštovanjem i zahvalnošću odnositi prema svojim učiteljima; da ću obavljati svoju profesiju savjesno i dostojanstveno; da će zdravlje pacijenta biti moja osnovna obaveza; da ću poštovati tajne koje su mi povjerene, čak $i$ poslije smrti pacijenta; da ću čuvati svim sredstvima koja su u mojoj moći, časnu i plemenitu tradiciju medicinske profesije; da će mi kolege biti braća i sestre; da neću dozvoliti da vjerska, nacionalna, rasna i politička pripadnost, ili socijalni položaj utječu na ispunjenje mojih obveza prema pacijentu; da ću gajiti najveće poštovanje prema ljudskom životu od njegovog samog početka čak i pod prijetnjom te da neću koristiti svoje medicinsko znanje protiv zakona humanosti“. Ova promjena dogodila se kao reakcija na nacističke zloupotrebe medicine.

23 Uzimajući pritom u obzir da „Roman Law deals with physical injury to a free man under the totally different set of rules of the actio iniuriarum “. Cit. Zietsman, C. J., op. cit., str. 96.

24 Ibid. 
kulturnoga kruga, ponekad ga kombinirajući s vlastitim srednjovjekovnim, u pravilu običajnim pravom. Odatle je on pretočen u moderne europske kodifikacije kaznenog i građanskog prava koje su mahom nastale krajem 18. i početkom 19. stoljeća. ${ }^{25}$

\section{ODGOVORNOST LIJEČNIKA U SREDNJOVJEKOVNOM PRAVU}

Različito od antičkog doba, srednji je vijek potpuno zapustio brigu o zdravlju te se tek od 16. stoljeća u europskim gradovima počinju osnivati prve bolnice sa stalnim liječničkim kadrom. Još ranije, oživljavanjem načela Hipokratove zakletve nakon uspostavljanja univerziteta i medicinskih škola u srednjovjekovnoj Europi, vladari Južne Italije Roger II. (12. st.) i Njemačke Frederick II. (13. st.) donose prve zakonske odredbe o državnom nadzoru nad radom liječnika. ${ }^{26}$ Pod utjecajem religijskih okultnih shvaćanja, srednji vijek karakteriziraju rasprave o čarobnjaštvu i magiji te je, općenito, stav prema liječničkoj profesiji bio u velikoj mjeri negativan, jer se smatralo da su liječnici prijetnja dogmi religijske prirode da su Krist i njegovi učenici bili superiorniji iscjelitelji. Upravo je zbog toga u 17. stoljeću bio kažnjen Sir Thomas Browne, engleski seoski liječnik iz Norfolka i autor filozofske rasprave pod nazivom Religio Medici. Na antagonizam prema liječnicima koji je u to vrijeme vladao ukazuje i knjiga autora Harveyja iz 1686. godine pod naslovom: The Conclave of Physicians, Detecting their Intrigues, Frauds, and Plots Against their Patients (Liječničke konklave, otkrivanje njihovih spletki, prijevara $i$ urota protiv njihovih pacijenata). Jedna od prvih pisanih kodifikacija europskog srednjovjekovnog kaznenog prava Constitutio Criminalis Carolina iz 1592. godine propisuje u odjeljku 134. kaznu za liječnike čiji su pacijenti umrli zbog njihova liječenja. ${ }^{27}$

U angloameričkom precedentnom pravu najstariji zabilježen slučaj nesavjesnog liječenja (medical malpractice $)^{28}$ Stratton $v$. Swanlond presuđen je 1374. godine $\mathrm{u}$ Engleskoj, u kojem je tuženi kirurg pokušao popraviti traumom unakaženu ruku tužitelja. Tužitelj je tvrdio da mu je kirurg zajamčio izliječiti ozljedu za razumnu naknadu, ali nakon poduzetog tretmana ruka je ostala teško deformirana. Tužba je

25 Jonjić, T., „Kaznena odgovornost liječnika kroz povijest“, Liječničke novine, 153, 10, 2016., str. 75.

26 Badjakova, V., op. cit., str. 2. To je i prva pojava tijela koje kontrolira rad liječnika u povijesti uopće. Šire Žarković Palijan, T., Kovač, M., Sarilar, M., Narić, S., Etička načela u kliničkim ispitivanjima na forenzičko-psihijatrijskoj populaciji, MEDIX, ožujak / travanj, 2012, god. X Vi I i, 98 / 99, str. 217.

27 Cit. Jesilow, D. P., Pontell, N. H., Geis, G., Medical criminals: physicians and white-collar offenses, 2 Just. Q.,1985, str. 150. Dostupno na http://heinonline.org

28 Etimološki, izraz malpractice potječe od latinske riječi "mal, malus" (zlo) i riječi grčkog izvora "praxis" (praksa), a koji izraz je 1765. godine skovao britanski pravnik Sir William Blackstone u knjizi "Komentari engleskih zakona," opisavši nemar liječnika ili nevješto liječenje kao "mal praxis" u značenju loše odnosno pogrešne prakse. The History and Origins of Medical Malpractice Litigation, dostupno http://www.bsmph.com/Articles/The-History-and-Origins-of-Medical-Malpractice Tako i Gârbo Viorica I., Civil Liability of Doctors and Their Insurance (Malpractice), Annals of the University of Oradea, 2013, 22, (1), str. 892. Dostupno na: http://anale.steconomiceuoradea.ro/ 
odbačena zbog proceduralne pogreške, međutim, sudac je naveo načela za buduće slučajeve koji su i danas prepoznati: liječnik ce biti odgovoran kada je pacijentova ozljeda rezultat njegove nepažnje odnosno nemara (negligence), ali neće odgovarati ako je uložio svu dužnu pažnju. ${ }^{29}$ Također, poznat je i slučaj Slater v. Baker $i$ Stapleton iz 1767. godine u kojem je Slater imao slomljenu nogu, koja nije bila dobro izliječena te je zatražio liječenje drugog liječnika, kirurga Bakera i ljekarnika Stapletona. Oni su ponovno slomili Slaterovu nogu i postavili mu „tešku čeličnu stvar sa zubima" za stiskanje i rastezanje, ali je rezultat bio loš. Slater ih je tužio te su tri kirurga posvjedočila da se ,čelična stvar" nije trebala uporabiti. Sud je, premda se radilo o prvom eksperimentu učinjenom s novim instrumentom, dodijelio tužitelju 500 funti (cca današnjih 60.000 funti). Pri tome, postavljen je standard po kojemu se može procijenjivati ponašanje liječnika: liječnik je odgovoran samo ako je drugi liječnik posvjedočio da je optuženik prekršio standarde medicinske skrbi. Međutim, sud je istovremeno naveo da stručnjak-vještak može svjedočiti samo ako je iz istog lokaliteta kao i tuženik, što je za tužitelja zasigurno izazivalo poteškoće u malim gradovima toga vremena, s obzirom na to da je svaki liječnik vjerojatno znao sve ostale liječnike u gradu. ${ }^{30}$ Žalbeni sud obrazložio je potvrdu dosuđene odštete činjenicom da se radikalni eksperiment sam po sebi može smatrti nesavjesnim liječenjem, barem ako je pritom izostao pacijentov pristanak. ${ }^{31}$

Značajni su izvori europskog srednjovjekovnog prava i statuti dalmatinskih primorskih gradova, u kojima se, pored mjera za održavanje zdravlja tadašnjeg stanovništva, ${ }^{32}$ pronalaze, doduše sporadično, i odredbe o pravnoj odgovornosti liječnika. Statut grada Splita iz 1312. godine sadržavao je odredbe koje se odnose na liječnike, pa tako u gl. XLVI. Treće knjige o postupku u građanskopravnim stvarima određuje liječničku nagradu: ako liječnik obeća da će za određenu nagradu liječiti odnosno izliječiti bolesnika od neke bolesti pa ga i izliječi, ali se taj bolesnik, najviše u roku od petnaest dana, ponovno razboli, liječnik tada ne smije primiti spomenutu nagradu. A ako ju je primio, dužan je tu nagradu vratiti, osim ako bi

29 Stetler, C. J., The History of Reported Medical Professional Liability Cases, 30 Temp. L.Q., 1956-1957, str. 367, dostupno na http://heinonline.org Isto i Gârbo Viorica I., op. cit., str. 888. Iz tog razdoblja poznat je i kazneni slučaj u Mađarskoj iz 1582. godine u kojemu je brijač (koji je u to vrijeme obavljao i kirurške zahvate) zbog nepropisnog liječenja pacijenta osuđen na zatvorsku kaznu. Cit. Varga, T., Szabó, A., Dósa, A., Bartha, F., Criminal Liability Of Physicians And Other Health Care Professionals In Hungary (Review Of Case Law Between 1996-2000), Med Law (2006) 25, str. 599. Dostupno na: http:// heinonline.org

30 The History and Origins of Medical Malpractice Litigation, dostupno http://www.bsmph.com/ Articles/The-History-and-Origins-of-Medical-Malpractice-Litigation.shtml.

31 Annas, J. G., ,Doctors, Patients, and Lawyers“, The New England Journal of Medicine, 367; 5, str. 446, dostupno na: nejm.org august 2, 2012.

32 Tako Glava LXXXVII Statuta Lastova pod naslovom "Naredbe o zdravstvu" kao mjere za održavanje dobrog zdravstvenog stanja stanovništva, a imajući na umu izbjegavanje zaraze, koju statut naziva haranje sveopćim pošastima, nalažu zdravstvenim službenicima: da vode računa o suzbijanju kuge, da budu pažljivi pri odlučivanju o propuštanju na otok osoba koje dolaze iz mjestâ sumnjivih zbog kuge i ako li se pak kuga ipak pojavi, da preuzimaju uobičajene mjere na njezinu suzbijanju. Pritom, statut ne objašnjava što se podrazumijeva pod pojmom "zdravstvenih službenika", nema podataka o postojanju učenih liječnika, ali je vjerojatno da su postojali ranarnici ili vidari, kao što je u to doba svugdje bilo. Cit. prema Milović-Karić, G., Milović, Đ., „Lastovski statut i zdravstvena kultura (Health Culture In The Statute Of Lastovo)“, Acta med-hist Adriat 2013., 11 (2), str. 287. 
(i dalje) liječio bolesnika od njegove ponovne bolesti ili ako bi bilo očito da se taj ponovno razbolio vlastitom krivnjom ili zbog nekog drugog novog uzroka. To zato što nije izliječen onaj bolesnik koji se uskoro opet razbolio. ${ }^{33}$ Trogirski statut iz 1322. godine u Drugoj knjizi o zločinima određuje kažnjavanje ljekarnika i liječnika koji se udruže u poslovanju. ${ }^{34}$ Srednjovjekovni statut grada Šibenika sadržavao je odredbe o liječnicima (naziva ih medicusima) i posebno o ranarnicima, pri čemu je važno da te dvije profesije u statutarnim propisima odvojeno tretira..$^{35} \mathrm{Na}$ jednome mjestu u statutu propisano je da su "plaćeni", dakle službeni liječnici dužni dojaviti knezu i Šibenskoj kuriji podatke o svim ranjenim i ozlijeđenim osobama, čim za to saznaju. ${ }^{36} \mathrm{Na}$ drugom se, pak, mjestu određuje da su plaćeni liječnici (medicusi) dužni prijaviti svaki slučaj ranjavanja, ali i dati stručno mišljenje o onim poslanicima koji nisu prihvaćali izbor s izgovorom da su bolesni. Liječnici su se pojavljivali sa svojim mišljenjima i u slučajevima u kojima se tzv. umobolnicima i slaboumnicima zabranjivalo sklapanje pravnih poslova, pa je, dakle, riječ o dužnostima liječnika kao vještaka. ${ }^{37}$

33 Statut grada Splita, splitsko srednjovjekovno pravo, Književni krug, Split, 1998., str. 511.

34 „Određujemo da se nijedan ljekarnik koji prima plaću od komune ne smije udruživati u poslovanje s liječnikom kojega komuna plaća kad se radi o stvarima ljekarne tog plaćenog ljekarnika ili pak liječnika koje služe za potrebe bolesnika. A ako bi se otkrilo da su liječnik ili ljekarnik u takvom ortaštvu, neka svatko od njih jer su napravili takav prekršaj plati trogirskoj komuni dvadesetpet libara malih, a to ortaštvo neka ne vrijedi i neka ne obvezuje. I taj liječnik i ljekarnik moraju se zakleti kada polažu prisegu (pri nastupu) svoje službe da nikako neće skupa osnivati ni imati ortaštvo. Također, kažnjavaju se liječnik i ljekarnik koji se udalje iz grada bez dozvole kneza i njegovih sudaca i to liječnik kaznom dvadesetpet libara malih, a ljekarnik i notar s pet libara“. Knjiga druga, 87. i 88. Statut grada Trogira, Književni krug, Split, 1988., str. 107. Statut grada Splita propisuje isto djelo u gl. XLVII. Komunalni liječnik ne smije se udruživati s ljekarnicima, s time da je propisana kazna od deset libara te ga svatko može tužiti i prijaviti. Statut grada Splita, str. 511.

35 Iz jednog popisa plaća, koji potječe iz 1454., vidi se da je liječnik (medicus) imao plaću od 200 dukata, ali da je u gradu postojao i ranarnik s plaćom od 100 dukata. Iz jednog kasnijeg popisa (iz 1532.) vidi se da su tada i liječnik i ranarnik imali istu plaću u iznosu od 600 libara. Cit. Milović, Đ., MilovićKarić, G., „Srednjovjekovni šibenski statut i briga za probleme zdravstvene kulture “, Acta med-hist Adriat, 2013., 11 (1), str. 73.

36 Knjiga šesta Statuta, poglavlje XXIII. pod naslovom: Plaćeni liječnici dužni su dojaviti ranjene. Knjige statuta..., 180. Prijave brijača, liječnika i dr. bile su temelj za početak sudskog postupanja $\mathrm{i}$ prema praktičnim priručnicima venecijanskog kruga među kojima je i neobjavljena Pratica criminale pei cancelieri dalmatinskog pravnika Jerolima Mičelovića Michielija, priručnika koji je nastao oko 1650. godine u Veneciji te je obrađivao zajedno s kaznenim i građansko pravo u obliku dijaloga između kancelara i koadjutora (kandidat za službu kancelara). Mičelović, J., Pratica criminale pei cancelieri, transkript, 2010., str. 24, cit. prema transkripciji i prijevodu pravnog povjesničara i romanista prof. dr. sc. Ž. Radića.

37 Budući da je grad (uz ranarnika) imao i učenog liječnika-medikusa, logičan bi zaključak bio da je u prije navedenim slučajevima medikus vještačio i određivao koji bi građanin spadao u kategoriju duševno defektnih ljudi. Cit. Milović, Đ., Milović-Karić, G., op. cit., str. 73. 


\section{PRAVNI DOKUMENTI O ODGOVORNOSTI LIJEČNIKA NAKON FRANCUSKE REVOLUCIJE}

Kraj 18. i početak 19. stoljeća obilježen je velikim socijalnim i političkim promjenama. Američka i Francuska revolucija bile su poticaj nastajanja nove klime političkog i socijalnog napretka u duhu prosvjetiteljstva, što se manifestiralo ubrzanim razvojem prirodno-medicinskih ${ }^{38} \mathrm{i}$ društveno-humanističkih znanosti. U tom smislu razvijali su se i pravo i medicina, pa primjeri liječničke odgovornosti ukazuju da se u novom vijeku počelo sve više voditi računa o krivnji liječnika kao i o nesavršenosti medicinskih znanja. Tako su u to vrijeme engleski sudovi, da bi uspostavili neki vanjski ili objektivni standard procjene liječničke vještine i znanja, počeli prepoznavati potrebu za određenim pravnim pravilom. U konačnici, prihvatili su pravilo po kojemu liječnika mogu smatrati odgovornim u onim slučajevima u kojima on poduzima manjkavu skrb nad pacijentom bilo iz neznanja ili nedostatka vještine. ${ }^{39}$ Mnogi od ranih slučajeva nesavjesne medicinske prakse predstavljaju zapravo kršenje ugovora liječnika i pacijenta na temelju kojega se liječnik obvezao na pružanje medicinske skrbi i liječenje. ${ }^{40}$ Tako je prva tužba za nesavjesno liječenje u SAD-u podnesena u državi Connecticut 1794. godine, ${ }^{41} \mathrm{u}$ kojoj je tužitelj tvrdio da je tuženik operirajući njegovu ženu na nevješt, neznalački i okrutan način prouzročio njenu smrt. Također, tvrdio je da mu je liječnik obećao da će zahvat izvesti vješto odnosno znalački i sigurno. Naime, gospođa Cross konzultirala je dr. Guthery za dijagnozu i liječenje problema koje je imala te je liječnik postavio dijagnozu i preporučio amputaciju dojke. Nakon njenog pristanka, dojka je amputirana, ali je poslije operacije došlo do krvarenja i pacijentica je umrla. Dr. Guthery je izrazio sućut suprugu, te mu je nakon nekoliko dana poslao račun za njezino liječenje i operaciju. Gospodin Cross je tužio liječnika te je sud odredio da liječnik mora platiti znatnu odštetu. ${ }^{42}$

38 Pod utjecajem prosvjetiteljstva započinje i stvaranje vlastitih programa edukacije za liječnike od strane već u 18. stoljeću osnovanih medical society, pa je tako 1807. godine osnovan medical college of the Medical Society of the County of New York. Cit. Doctor of medicine profession (MD). Dostupno na: https://www.nlm.nih.gov/medlineplus.

39 Hale, T. E., „Emergency Medical Treatment“, 10 Wm. \& Mary L. Rev., 1968.-1969., str. 957. Dostupno na http://heinonline.org.

40 „At the beginning of the 17th century, medical practice in England was divided into three groups: the physicians, the surgeons, and the apothecaries“. Međutim, ovo razlikovanje liječnika, kirurga i ljekarnika nije preživjelo u kolonijalnoj Americi, jer su engleski fakultetski obrazovani liječnici stigavši u Ameriku očekivali da obavljaju i operacije i ordiniraju lijekove. Već 1766. godine ustrojavaju se prve organizacije odnosno društva medicinskih stručnjaka u kolonijama, npr. Medical Society of New Jersey. Stručna društva počela su regulirati medicinsku praksu licenciranjem praktičara već od 1760. godine te su sve do ranih 1800-ih bila zadužena za utvrđivanje propisa, standarda prakse kao i ovjere liječnika. Cit. prema Doctor of medicine profession (MD).

41 Šire o slučaju Cross v. Guthery u McClurg, J. A., „Fight Club: Doctors vs. Lawyers-A Peace Plan Grounded in Self-interest“, 83 Temp. L. Rev. 2010.-2011., str. 315. Dostupno na: http://heinonline.org. U literaturi se navodi da se događaj zbio prije Američke revolucije odnosno godine 1775. Gârbo Viorica I., op. cit., str. 888 .

42 Ibid. Godine 1803. u Manchesteru Tomas Percival tiska prvi "Kodeks etičkih pravila za liječnike”. Annas, J. G., op. cit., str. 445. 
Vrhovni sud države Connecticut definirao je 1832. godine standard medicinske skrbi jezikom koji se, univerzalno, koristi i danas. Prvostupanjski sud donio je presudu u korist tužitelja, pa je liječnik kao tuženik podnio žalbu u kojoj je tvrdio da su zakonski propisi koji vrijede u državi Connecticut takvi da za odštetnu odgovornost kirurga zbog nesavjesnog rada zahtijevaju najmanje njegovo grubo neznanje ili krajnju nepažnju. U žalbenom postupku Vrhovni sud potvrdio je prvostupanjsku presudu navodeći da: “... ako je postojala ili nemarnost ili nedostatak uobičajene mjere marljivosti, pažnje i vještine, onda je tužitelj imao pravo da se oporavi". ${ }^{43}$ Zanimljiv je i slučaj u kojemu je sudjelovao Abraham Lincoln, koji je prije nego je postao predsjednik SAD-a, bio istaknuti odvjetnik (litigant) u parničnim postupcima za naknadu štete zbog nesavjesnog liječenja. On je 1855. godine zastupao dva liječnika iz Illinoisa u tužbi tužitelja stolara koji je pretrpio bilateralne bedrene lomove kada je dimnjak pao na njega. Tuženi liječnici nisu očekivali da će pacijent preživjeti, pa su mu postavili noge u udlage, a kada su udlage uklonjene, desna je noga ostala iskrivljena. Tužitelj je angažirao šest odvjetnika za svoj slučaj uz veliku podršku javnosti. Lincoln je uspio dobiti nekoliko odgoda suđenja, zastupajući teoriju da je najbolja obrana upravo protek vremena. Kada je suđenje konačno započelo, tužiteljevi odvjetnici predstavili su ukupno 15 liječnika svjedoka i 21 ostalih svjedoka dok su tuženici predstavili 12 drugih liječnika. Presuda nikada nije donesena niti se postupak ikad ponovio. Tijekom suđenja Lincoln je upitao tužitelja može li hodati, na što je ovaj potvrdno odgovorio, ali se žalio da mu je desna noga toliko kratka da šepa. Lincoln je na to odgovorio: "Dobro! Ono što bih vam ja savjetovao da napravite jest da se spustite na koljena i zahvalite vašem nebeskom Ocu i ovoj dvojici liječnika da imate bilo koju nogu za stajati". ${ }^{44}$

Društvene promjene, kao i promjene u medicini, postale su plodno tlo da se parnice za nesavjesno liječenje ukorijene te je između 1840. i 1860. godine došlo do prave poplave tužbi za nesavjesno liječenje. Paradoksalna je činjenica da su napredak u medicinskoj znanosti i poboljšanja medicinske tehnike zapravo potaknuli porast parnica za nesavjesno liječenje. Tužbe za nesavjesno liječenje između 1790. i 1835. godine gotovo da nisu postojale, da bi nakon toga pacijenti iznenada počeli tužiti liječnike, i to ne šarlatane nego ugledne liječnike koji su tako postali mete gotovo revolucionarnih i jedinstvenih optužbi za nemar. ${ }^{45}$ Broj slučajeva pred apelacijskim sudovima porastao je za 950 posto, dok je broj stanovnika porastao za samo 85 posto. Većina je Amerikanaca u 17. i 18. stoljeću vjerovala da je liječnički neuspjeh izričiti izraz božanskog te je skromno prihvaćanje božanske volje pravi odgovor na neuspjeh liječnika, a ne parnica protiv njega. Takav fatalistički stav počeo se mijenjati tijekom prve polovice 19. stoljeća, pa je umjesto fatalizma sve više raslo

43 Ibid.

44 Ovakvo Lincolnovo unakrsno ispitivanje odražavalo je stil koji se koristio u 19. stoljeću u sudskim postupcima, osiguravajući publici vjerojatno više zabave nego što je to danas. Šire o tom suđenju Lincoln's "Chicken Bone" case - The first medical malpractice trial in McLean County, Posted by Mac on July 15, 2019. Dostupno na: https://thelogcabinsage.com/lincolns-chicken-bone-case-the-firstmedical-malpractice-trial-in.

45 Struve, T. C., ,Doctors, The Adversary System, and Procedural Reform In Medical Liability Litigation“, 72 Fordham L. Rev., 2003.-2004., str. 949. Dostupno na http://heinonline.org. 
uvjerenje da ljudsko djelovanje, a ne božanska volja, određuje tijek događaja. Iz toga je slijedilo prihvaćanje da su ljudi, a ne Bog, odgovorni za medicinske ishode, pa je manje radikalno tužiti nekog liječnika za nepovoljan ishod. Također, gubitak društvenog položaja liječnika, koji je započeo već u drugoj polovici 18. stoljeća, doprinio je povećanju broja tužbi protiv liječnika. ${ }^{46} \mathrm{~S}$ obzirom na to da se nadzor nad medicinom nije poduzimao sve do druge polovice 19. stoljeća, zanimljivo je da su i neki ugledni liječnici, kao Nathan Smith s Yalea i R. E. Griffith sa Sveučilišta u Pennsylvaniji, zapravo uvidjeli koristi od sudskih slučajeva medicinske odgovornosti. Oni su vjerovali da takve tužbe pomažu da se izvrši standardizacija tj. da se postave standardi kvalitete u medicinskoj struci koji su do tada bili slabo regulirani. ${ }^{47}$

Američki liječnici i ostali medicinski djelatnici osnovali su već 1847 . godine nacionalno medicinsko udruženje, pod nazivom American Medical Association (AMA), koje danas ima velik utjecaj u pitanjima koja se odnose na zdravstvenu zaštitu u SAD-u. AMA je imala nekoliko ciljeva, među ostalima i standardizaciju ne samo edukacije liječnika nego i medicinske prakse, čime bi se unaprijedio društveni i gospodarski položaj medicinske struke. Također, željelo se poboljšati znanstveno lice medicine kako bi ona bila učinkovitija i cjenjenija. Međutim, razvijanjem standarda liječničke prakse posljedično su stvorena i mjerila po kojima se presuđivala njihova odgovornost, jer upravo zbog činjenice da su uspostavljeni standardi proizlazi i mogućnost da se od njih i odstupi, što rezultira tužbama za nesavjesno liječenje. Još više, uspostavljanjem sustava osiguranja od nesavjesnog liječenja i medicinskih grešaka, svi su liječnici od kraja 19. stoljeća postali potencijalne „mete“ za tužbe i optužbe. ${ }^{48}$

I europske države nakon Francuske revolucije sve više propisuju kaznenu odgovornost medicinskih djelatnika. Tako Kazneni zakon Sjevernonjemačkog saveza iz 1870. godine propisuje kažnjavanje svake osobe koja je licencirana za profesionalnu praksu ako, unatoč općepoznatim pravilima medicinske struke, nanese štetu zdravlju ljudi nemarno ili nepažljivo propuštajući dužnu pažnju ${ }^{49}$ Prva posebna odredba mađarskog kaznenog zakonodavstva koja se bavila protupravnim ponašanjem profesionalaca u svojoj struci pojavila se 1878. godine baš u vezi s ozljedom nanesnom od strane liječnika: ako je nanesena ozljeda posljedica stručnog neiskustva, nemara ili povrede pravila struke, kaznit će se zatvorom do godine dana. Pri tome su određena dva oblika nepropisne medicinske prakse: "luxuria" i "negligence" tj. samopouzdanje i nemarnost kao kriteriji individualne odgovornosti. Ako je liječnik prouzročio smrt pacijenta, bila je propisana kazna zatvora do tri

46 U 19. stoljeću većina parnica za obeštećenje odnosila se na liječenje ortopedskih ozljeda. Ibid.

47 Zlatno doba samoregulacije u Europi i Americi predstavlja doba kada se liječnici počinju udruživati u komore, što datira već od 18. stoljeća, a zbog postizanja standarda kvalitete, standarda sigurnosti, etičkih standarda, samoregulacije i postizanja najboljeg ishoda za medicinsku njegu pacijenata, dakle, zbog uspostavljanja profesionalnih standarda. Wapner, L., Aspects and functions of Professional Autonomy and Self-Regulation, EFMA Forum, Riga, 2013.

48 The History and Origins of Medical Malpractice Litigation.

49 Cit. prema Varga, T., Szabó, A., Dósa, A., Bartha, F., op. cit., str. 594. 
godine te druge mjere nakon osude u smislu sigurnosnih mjera i pravnih posljedica osude. $^{50}$

U to vrijeme nastaje i prva definicija liječničke pogreške koju je 1879. godine dao njemački znanstvenik, liječnik i začetnik moderne medicinske patologije Rudolf Carl Virchow (1821. - 1902.), službujući kao patolog na sveučilišnoj klinici Charité u Berlinu: liječničku pogrešku (Kunstfehler; Fehler der Arzter) predstavlja povreda ili kršenje općepriznatih pravila struke zbog nedostatka dužne pažnje i opreza. ${ }^{51}$

U 19. stoljeću zbio se i slučaj Neisser koji je utjecao na donošenje prvog poznatog pravnog akta kojim se uređuje područje istraživanja na ljudima Direktive pruskog ministra bogoštovlja, prosvjete $i$ zdravlja iz 1900. godine. ${ }^{52}$ Njemački dermatovenerolog Albert Neisser proveo je 1892. godine istraživanje cijepljenjem zdravih ljudi serumom iz oboljelih od sifilisa, injektirajući serum u osam mladih žena koje su zbog drugih razloga bile pacijentice u bolnici. Kako bi pronašao metode prevencije sifilisa, nadajući se da će pacijentice razviti imunitet na sifilis, nije ih obavijestio o postupku niti je dobio njihov pristanak. Neisser je za provođenje medicinskog istraživanja na ljudima kažnjen u disciplinskom postupku pred Carevinskim disciplinskim sudom dok je njegova kaznena odgovornost otklonjena zbog nastupa zastare. Pri tome je izraženo značajno stajalište tadašnjih pravnika da se provođenjem neterapeutskog istraživanja na ljudima bez njihova pristanka ostvaruju obilježja kaznenog djela tjelesne ozljede. ${ }^{53}$

U hrvatskom pravu tradicionalno je poznata prekršajna i kaznena odgovornost medicinskih djelatnika. Tako, u Kaznenome zakonu o zločinstvih, prestupcih $i$ prekeršajih cara Franje Josipa I. iz 1852. godine, koji je važio za cijelu carevinu, osim vojne Krajine, sve do 1 . siječnja 1930. godine, pored glave osme („O prestupcih i prekršajih suprot sigurnosti života“, §§ 335-392), bila je propisana i glava deveta („O prestupcih i prekeršajih suproti zdravju“ $\S \S 393-408$ ), dok je glava šesnaesta prvoga dijela zakona nosila naslov „O uzrokovanom pometnutju“ (§§ 144-148). ${ }^{54}$

50 U isto vrijeme, države common lawa ne propisuju posebno djelo nego se liječnici, ako je došlo do smrti pacijenta, mogu kazniti za opće kazneno djelo ubojstva. Ibid., str. 595.

${ }_{51}$ "Eine Verstoss gegen die allgemein anerkannten Regeln in Heilkunst infolge eines Mangels an gehariger Aufmerktsamkeit oder Vorsicht". Ibid., str. 594.

52 Šire o direktivi Roksandić Vidlička, S., Galiot, V., „Eksperimenti na ljudima kao zločin protiv čovječnosti: od nürnberškog medicinskog suđenja do predmeta Pfizer“, Godišnjak Akademije pravnih znanosti Hrvatske, vol. VII, 1, 2016., str. 207.

53 Cit. Ibid, str. 208. i Vollmann, J., Winau, R., ,Informed consent in human experimentation before the Nuremberg Code“, British Medical Journal, 1996., 313:7070, str. 1446. Dostupno na http://www.ncbi. nlm.nih.gov/pmc.

54 Za prouzročenje ,,pometnutja“ kažnjavani su ne samo trudnica, nego još strože onaj otac djeteta koji je u izvršenju pobačaja sudjelovao, ali se teškom tamnicom u trajanju od jedne do pet godina prijetilo i trećoj osobi koja je ,suprot znanju $i$ volji matere“ sudjelovala u pobačaju ili ga pokušala izazvati. Jonjić, T., „Kaznena odgovornost liječnika kroz povijest“, Liječničke novine, 154, 11, 2016., str. 87. 
Posebno je važna odredba čl. 356. o krivnji liječnika neznanstvom ${ }^{55}$ dok je odnos judikature prema kaznenoj odgovornosti liječnika vidljiv iz presude Vrhovnoga suda od 2. lipnja 1858. godine u postupku protiv neimenovanog liječnika koji je propisao neke lijekove četveromjesečnom dojenčetu koje je patilo od proljeva i povraćanja. Međutim, ljekarnik je ocijenio kako je propisana doza s obzirom na dob i stanje djeteta prevelika, pa ju je na vlastitu ruku smanjio. Dijete je umrlo, a inkriminiran je samo liječnik, s obrazloženjem da je medicinskim vještačenjem ustanovljeno kako je i smanjena doza propisanih lijekova, ona koju je ljekarnik faktično dao, bila takva da je prouzročila smrt dojenčeta, pa je liječnik iz nehaja kriv za njezino nastupanje. Drugo je vještačenje proveo Medicinski fakultet u Beču koji je došao do zaključka da je optuženi liječnik propisivanjem velike doze lijekova doista napravio propust, ali da to nije prouzročilo smrt djeteta, i to ne samo zbog toga što je ljekarnik smanjio propisanu dozu nego i zbog toga što je djetetov organizam već bio toliko slabašan da nije mogao apsorbirati ni tu smanjenu dozu, pa bi dijete vjerojatno umrlo posve neovisno o bilo kakvim lijekovima i njihovu doziranju. ${ }^{56}$

\section{ODGOVORNOST LIJEČNIKA ZA NACISTIČKE „MEDICINSKE“ ZLOČINE}

Povijest je, nažalost, pokazala da liječnici mogu biti počinitelji i najstrašnijih tzv. medicinskih zločina kao zločina protiv čovječnosti. ${ }^{57}$ Posebnu okrutnost iskazali su nacistički liječnici u koncentracijskim logorima koje bi se, parafrazirajući antičke filozofe Antiphona i Philếmōna, doista moglo opisati ne kao liječnike već kao nekažnjive ubojice. Povijest medicinskih eksperimenata na ljudskim subjektima vrvi primjerima od kojih je najgore i najokrutnije među njima otkrilo suđenje nacističkim ratnim zločincima u Nürnbergu. Suđenje liječnicima (the Doctors' Trial ili the Medical Case), održano od prosinca 1946. do kolovoza 1947. godine, otkrilo je javnosti strašne eksperimente provođene na desetinama tisuća zatvorenika u koncentracijskim logorima, eksperimente koji su potresli osnovne koncepte

55 „Liečnik, koi u liečenju kojega bolesnika učini takovih pogrešakah, odakle se vidi njegovo neznanstvo, ako nastane odtuda težka tielesna ozleda, tvori se krivcem prekeršaja, ako li bolestnik umre, krivcem prestupka, i ima mu se radi toga praktika zabraniti dotle, doklegod nedokaže putem novoga izpita, da si je pribavio znanja, koja su mu manjkala“. Analogna tomu bila je odgovornost ranarnika (Wundarzt): „Ima se uporavit ova kazna i suprot ranarniku, ako neviešto operira kojega bolestnika, ter prouzroči time posliedicah, pomenutih u paragrafu predidućem“ (§ 357. „Krivnja ranarnika neznanstvom“). Ibid.

56 Presuda je objavljena u Allgemeine Österreichische Gerichtszeitung 7. kolovoza 1858. Cit. Ibid.

57 Povijest nas uči o posljedicama nepoštovanja temeljnih etičkih prioriteta medicine i štete za medicinsku struku prouzročenu politički utvrđenim prioritetima: „,The events in Nazi Germany provide vivid examples of harm to the values of the medical profession caused by politically determined priorities." Cit. Francis, K. C., „Medical ethos and social responsibility in clinical medicine“, Journal of Urban Health: Bulletin of the New York Academy of Medicine, vol. 78, 1, March 2001, str. 31. 
etike, medicine, znanosti i humanosti. ${ }^{58}$ Suđenje najznačajnijim liječnicima Trećeg Reicha ${ }^{59} \mathrm{u}$ predmetu The United States of America against Brandt et al. ostavilo je neizbrisiv trag u razvoju medicinskog prava i bioetike. ${ }^{60}$

Nakon što je Hitler 1939. godine odobrio provođenje programa T-4 (»Aktion $T 4$ «) kojom se legalizirala eutanazija nedostojnih, nacisti poduzimaju plansko istrebljivanje osoba s tjelesnim i mentalnim teškoćama, djece s fizičkim oštećenjima, starijih osoba, osoba s duševnim smetnjama, neizlječivo bolesnih, osoba miješane rase, homoseksualnih i biseksualnih osoba te pripadnika »inferiornih rasa « odnosno Židova, Roma i Slavena ${ }^{61}$ Taj je program, najprije na području Njemačke potom i na okupiranim područjima, trajao sve do 1945. godine. Dr. Brandt je odredio liječnike koji će pod krinkom »smrt iz milosrđa « provesti program T4 ili program uništenja života nevrijednih življenja, uzrokujući ubojstva oko 5000 djece s teškoćama u razvoju, više od 70.000 odraslih osoba i sterilizaciju 400.000 osoba. To je bio samo uvod u »konačno rješenje« (njem. Die Endlösung) i stradanje oko 11 milijuna ljudi. Procjenjuje se da je u masovna ubojstva u koncentracijskim logorima bilo uključeno oko 200 liječnika od kojih su mnogi provodili različite neetične eksperimente na zatvorenicima te se govori o 30 različitih vrsta eksperimenata: smrzavanjem, inficiranjem malarijom, eksperimente zacjeljivanja lomova kostiju, eksperimente $u$ vezi sa sterilizacijom, desalinizacijske eksperimente i $\mathrm{dr}^{62}$ Medicinski eksperimenti izvodili su se i radi testiranja lijekova i metoda liječenja za bolesti i ozljede s kojima su se susretali njemački vojnici. Tako je, zbog širenja tuberkuloze, nacistički liječnik Heissmeyer u logoru Neuengamme u blizini Hamburga provodio eksperimente da bi utvrdio postoji li prirodni imunitet na tu bolest. Kako je smatrao da tuberkuloza u osnovi nije zarazna bolest već pogađa iscrpljene organizme, a naročito one lošije kakve imaju Židovi, ubrizgavao je žive tuberkulozne bacile u pluća zatvorenika prisiljenih na sudjelovanje u eksperimentu. Isti je liječnik za potrebe istraživanja uklonio limfne žlijezde s ruku dvadesetero židovske djece, a da bi sakrio dokaze pred

58 Diskriminacijska ideologija eugenike jasno je utjecala na donošenje brojnih sterilizacijskih i imigracijskih zakona, a upravo je ona postavila temelj za nacističke eksperimente u logorima. Cit. Štojs, T., op. cit., str. 92. Posljedica je usvajanja teorija socijalnog darvinizma pojava pokreta "racial hygiene" i porast njegovih pristalica 30 -tih godina 20. stoljeća među njemačkim liječnicima. Cit. Francis, K. C., op. cit., str. 31 .

59 U vrijeme Weimarske Republike liječnici su dijelili sudbinu brojnih sunarodnjaka kad je posrijedi visoka stopa nezaposlenosti i gubitak socijalnog ugleda. Godine 1929. osnovan je Nationalsozialistischer Deutscher Ärtztebund (Nacionalsocijalističko njemačko medicinsko udruženje). Prema objavljenim istraživanjima, do siječnja 1933. već je više od polovice njemačkih liječnika bilo učlanjeno u Nacionalsocijalističku stranku, a u 1942. godine njihov broj iznosio je 38.000. Cit. prema Tucak, I., „Suđenje nacističkim liječnicima u Nürnbergu - 'liječničko suđenje'“, Liječničke novine, 177, ožujak 2019., str. 78 .

${ }^{60}$ Roksandić Vidlička, S., Galiot, V., op. cit., str. 187. Međutim, ovo suđenje nije obuhvatilo i zločine nad njemačkim stanovništvom, s obzirom na to da je u Njemačkoj 1933. donesen Zakon o sprečavanju genetski bolesnog potomstva kojim je za određene kategorije osoba bila predviđena obvezna sterilizacija. U razdoblju od 1933. do 1939. njemački liječnici sterilizirali su, pozivajući se na taj Zakon, između 360.000 i 375.000 osoba. Cit. prema Tucak, I., op. cit., str. 79.

${ }_{61}$ Šire o nastanku programa Longerich, P., Holocaust: The Nazi Persecution and Murder of the Jews, Oxford University Press, 2010.

62 Roksandić Vidlička, S., Galiot, V., op. cit., str. 198. Svi su se eksperimenti mogli podijeliti na tri glavne skupine: vojne, medicinske i rasno motivirane eksperimente. Cit. Stojs, T., op. cit., str. 92. 
nadolazećim sovjetskim vojnicima, naredio je da se sva ta djeca objese. ${ }^{63}$ Nacistički liječnik Carl Clauberg, vođen zadatkom stvaranja superiorne arijevske rase, provodio je u Auschwitzu nasilno oplođivanje ili steriliziranje nad 300 zatvorenica u dobi između 20 i 40 godina. Himmler je uskoro Claubergova istraživanja preusmjerio na pronalazak jeftine metode sterilizacije da bi se ona mogla primijeniti na milijune neželjenih u logorima i Trećem Reichu općenito. ${ }^{64}$ Nakon rata Sovjeti su osudili Clauberga na 25 godina zatvora, ali je u okviru njemačko-sovjetske razmjene pušten već nakon 7 godina. ${ }^{65}$

Najzloglasniji među nacističkim liječnicima bez sumnje je Josef Mengele, poznat i pod nadimcima Anđeo smrti i Bijeli anđeo, jer je u bijeloj kuti dočekivao vagone novih logoraša i hladnokrvno određivao koji su sposobni za rad, a koje treba odmah poslati u plinsku komoru. Mengele je najveći dio svog rada, zaluđen nacističkom ideologijom rasne čistoće, posvetio eksperimentima na blizancima kako bi se povećanjem broja djece rođene jednim porodom pridonijelo bržem umnožavanju arijevske rase ${ }^{66}$ Od otprilike 1000 parova blizanaca koji su sudjelovali u pokusima samo je oko 200 parova preživjelo. Mengele u siječnju 1945. godine bježi iz Auschwitza te se nekoliko godina pod lažnim identitetom skriva u rodnom Gunzburgu da bi 1949. prebjegao u Argentinu gdje se sve do svoje smrti 1979. godine uspješno skrivao uz pomoć bivših nacista i nikada nije odgovarao za počinjene zločine.

U predmetu Brandt et al., šesnaest od 23 optuženika (od kojih su 20 bili liječnici) proglašeni su krivima za ratne zločine i zločine protiv čovječnosti, sedam ih je pogubljeno, petorica su osuđena na kaznu doživotnog zatvora i četvoro na vremenske kazne zatvora dok je sedam optuženika oslobođeno. ${ }^{67}$ Opravdano je, doista, upitati se kako su nacistički liječnici umjesto iscjelitelja postali mučitelji, ili,

63 Logorski liječnik Rascher prisilio je oko 200 zatvorenika na boravak u dekompresijskoj komori kako bi simulirao velike nadmorske visine, a često je i secirao mozak još živih logoraša. Štojs, T., op. cit., str. 103 .

64 Mnoge je žene tjerao na seksualne odnose s muškim zatvorenicima, a često bi se i psihički iživljavao nad njima govoreći im da ih je oplodio životinjskim sjemenom i da sada u njima raste čudovište. Poznato je da su mnoge žene nakon sudjelovanja u Claubergovim eksperimentima počinile samoubojstvo. Tisućama zatvorenika pritom su unakažene genitalije: žene su sterilizirali injekcijama agresivnih nagrizajućih tvari unesenih u maternice, a muškarcima su zračili testise te ih naknadno kastrirali da bi utvrdili nastale patološke promjene. Rosalinde de Leon, jedna od preživjelih židovskih logorašica, svjedočila je kako su ženama rekli da će, ukoliko odbiju sudjelovanje u istraživanju, biti poslane u Birkenau, odnosno u tamošnje plinske komore. Protivljenje je bilo potpuno besmisleno, a žene su nakon primljenih injekcija trpjele takve bolove da su im medicinske sestre morale sjediti na rukama da se ne bi ozlijedile. Ibid. str. 104.

65 Po povratku u Njemačku, Clauberg se zaposlio na klinici na kojoj je radio prije rata, no njemačke su ga vlasti uskoro ponovno uhitile, ali je umro u ćeliji prije početka suđenja. Ibid. str. 104.

66 Eva Moses, jedna od preživjelih blizanki na kojima je Mengele provodio pokuse, svjedočila je kako ju je u dobi od 9 godina zarazio njoj nepoznatom bakterijom i ostao iznenađen što od nje nije umrla te kako je operacijom spajanja romskih blizanaca pokušao od njih stvoriti sijamske blizance, ali uslijed gangrene su poslije tri dana umrli. Čim bi jedan od blizanaca preminuo, Mengele je injekcijom usmrtio drugog da bi mogao istovremeno detaljno pregledati njihove organe, a mnoge je parove blizanaca za potrebe obdukcije usmrtio odmah po dolasku u logor. Ibid. str. 105.

67 Annas, G. J., Grodin, M. A., „Reflections on the 70th Anniversary of the Nuremberg Doctors' Trial“, Am J Public Health. 2018 Jan; 108 (1):10-12; i Roksandić Vidlička, S., Galiot, V., op. cit., str. 203. 
drugim riječima, zbog čega su liječnici-zločinci ilustrirali potpunu dehumanizaciju i objektivizaciju čovjeka njegovim svođenjem na sredstvo za zločinačke ciljeve? ${ }^{68}$

\section{ZAKLJUČNE NAPOMENE}

Prikaz povijesti liječničke višestruke odgovornosti ukazuje da današnji sustav profesionalne pravne odgovornosti liječnika predstavlja u suvremenim društvima srednji put između dviju krajnosti: okrutnosti Hamurabijeva talionskog načela po kojemu je bila propisana kazna odsijecanja ruke liječniku koji bi svojom nepažnjom skrivio smrt slobodnog čovjeka i Platonova laksizma u kojem je smatrano da je liječnik uvijek nedužan pred zakonom. U starom vijeku njihova je odgovornost ovisila o klasnoj pripadnosti pacijenta, u drevnom egipatskom društvu liječnici su se morali strogo pridržavati pravila i nisu bili izuzeti od odgovornosti za nesavjesno obavljanje svoje djelatnosti, dok je nedostatak kažnjavanja za nesavjesno liječenje u antičkoj Grčkoj značajna razlika u odnosu na profesionalnu odgovornost danas. Prekretnicu je donijelo rimsko pravo koje je postavilo pravna pravila za široko tumačen pojam liječničke pogreške, jer je liječničku djelatnost već u antičkom Rimu uređivala sama država. Od tada do danas postupno se uobličavala pravna odgovornost liječnika u slučaju pogreške kao ključnom elementu za oblikovanje modernog uređenja odgovornosti liječnika. Rimski model odgovornosti liječnika preuzet je u srednjovjekovnom pravu, kojemu pripadaju i statuti dalmatinskih primorskih gradova, dok se u novom vijeku počelo sve više voditi računa o krivnji liječnika, ali i o nesavršenosti medicinskih znanja. Najvažnija ostavština suđenja njemačkim liječnicima za njihovo sudjelovanje u užasnim nacističkim zločinima jest uspostava pravne odgovornosti za genocid, ratne zločine i zločine protiv čovječnosti te donošenjem Nürnberških načela i Nürnberškog kodeksa prevencija kršenja temeljnih ljudskih prava zlouporabom medicinske profesije.

68 Pokušaj da se odgovori na pitanje jesu li mnogi od liječnika, zaluđeni nacističkom ideologijom, doista vjerovali da čine dobro, jer su zatvorenici u logorima bili smetnja, teret društva koji treba odstraniti, ili je neke vodila posve deformirana želja za znanjem ili bolesna želja za moći i slavom, ili je kod onih liječnika koji su isprva nevoljko sudjelovali u masovnim ubojstvima, naposljetku, prevladala realnost logora i njihova vlastita nacistička ideologija, dao je Lifton. Nakon što je intervjuirao preživjele doktore i zatvorenike Auschwitza, Lifton je zaključio da se ponašanje nacističkih liječnika može objasniti kroz psihološki proces dubliranja (doubling): suočeni s užasima logora, liječnici su uz »normalno sebstvo« razvili i dodatno »Auschwitz sebstvo« te su zahvaljujući dubliranju identiteta mogli sudjelovati u ubojstvima, a da sebe nisu promatrali kao ubojice već prije kao one koji moraju obaviti prljav, ali nužan posao. Cit. Lifton, J. R., Nazi Doctors at Auschwitz, 2014., August, 09. Dostupno na http://www.uni.edu/ sandstrk. 


\section{LITERATURA}

1. Annas, J. G., „Doctors, Patients, and Lawyers“, The New England Journal of Medicine, 367; 5, 2012. Dostupno na: nejm.org august 2, 2012.

2. Annas, G. J., Grodin, M. A., „Reflections on the 70th Anniversary of the Nuremberg Doctors' Trial“", Am J Public Health. 2018 Jan; 108 (1).

3. Badjakova, V., ,The Responsibility of The Healthcare Workers Shown Through The Prism of The Judicial Practise“, Iustinianus Primus Law Review, vol. VI, br. 2, 2015.

4. Blagojević, I., „Priznanje prava na naknadu štete povodom neželjenog rođenja deteta u američkom pravu i osiguranje lekara i pacijenata“, Evropska revija za pravo osiguranja, 2013., vol. 12, br. 4. Dostupno na: scindeks-clanci.ceon.rs/data/pdf/2334.

5. Čehok, I., Filozofija i medicinska etika, Druš. istraž. Zagreb/god. 5 (1996.), br. 3-4 (23-24).

6. Doctor of medicine profession (MD). Dostupno na https://www.nlm.nih.gov/ medlineplus.

7. Francis, K. C., „Medical ethos and social responsibility in clinical medicine“, Journal of Urban Health: Bulletin of the New York Academy of Medicine, vol. 78, 1, March 2001.

8. Gârbo Viorica I., „Civil Liability of Doctors and Their Insurance (Malpractice)“, Annals of the University of Oradea, 2013., 22, (1). Dostupno na: http://anale. steconomiceuoradea.ro.

9. Hale, T. E., „Emergency Medical Treatment“, 10 Wm. \& Mary L. Rev., 1968.-1969.

10. Jesilow, D. P., Pontell, N. H., Geis, G., Medical criminals: physicians and whitecollar offenses, 2 Just. Q., 1985.

11. Joffe, A., Egypat and Syromesopotamima in the 4th Milenium: Implicate of the New Cronology, 2000.

12. Jonjić, T., „Kaznena odgovornost liječnika kroz povijest“, Liječničke novine, 153, 10, 2016. i 154, 11, 2016.

13. Lifton, J. R., Nazi Doctors at Auschwitz, 2014., August, 09. Dostupno na http://www. uni.edu/sandstrk.

14. Lincoln's "Chicken Bone" case - The first medical malpractice trial in McLean County, Posted by Mac on July 15, 2019. Dostupno na: https://thelogcabinsage.com/ lincolns-chicken-bone-case-the-first-medical-malpractice-trial-in-mclean-county.

15. Longerich, P., Holocaust: The Nazi Persecution and Murder of the Jews, Oxford University Press, 2010.

16. McClurg, J. A., „Fight Club: Doctors vs. Lawyers-A Peace Plan Grounded in Selfinterest“", 83 Temp. L. Rev. 2010.-2011.

17. Mičelović, J., Pratica criminale pei cancelieri, transkript, 2010.

18. Milović, Đ., Milović-Karić, G., ,Srednjovjekovni šibenski statut i briga za probleme zdravstvene kulture“, Acta med-hist Adriat, 2013., 11 (1).

19. Milović-Karić, G., Milović, Đ., „Lastovski statut i zdravstvena kultura (Health Culture In The Statute Of Lastovo)“, Acta med-hist Adriat 2013., 11 (2). 
20. Nenadović, M., Medicinska etika, Beograd, 2007.

21. Roksandić Vidlička, S., Galiot, V., „Eksperimenti na ljudima kao zločin protiv čovječnosti: od nürnberškog medicinskog suđenja do predmeta Pfizer“, Godišnjak Akademije pravnih znanosti Hrvatske, vol. VII, 1, 2016.

22. Statut Grada Splita, splitsko srednjovjekovno pravo, Književni krug, Split, 1998.

23. Statut grada Trogira, Književni krug, Split, 1988.

24. Stetler, C. J., „The History of Reported Medical Professional Liability Cases“, 30 Temp. L. Q., 1956-1957.

25. Struve, T. C., „Doctors, The Adversary System, and Procedural Reform In Medical Liability Litigation“, 72 Fordham L. Rev., 2003.-2004.

26. Swanepoel, M., „The Development of the Interface between Law, Medicine and Psychiatry: Medico-Legal Perspectives in History“, Potchefstroom Electronic Law Journal, 2009.; 12 (4). Dostupno na: https://doaj.org/article/0e4ec424a402434.

27. Šeparović, Z., „Život doveden na rub“, Rev. za soc., Zgb., Vol. XXI (1990.), No 2.

28. Štojs, T., „Istraživanja na ljudskim subjektima - povijesni razvoj, načela i primjeri neetičnih postupanja“, Nova prisutnost 12 (2014.) 1.

29. The History and Origins of Medical Malpractice Litigation, dostupno na http://www. bsmph.com/Articles/The-History-and-Origins-of-Medical-Malpractice.

30. Tucak, I., „Suđenje nacističkim liječnicima u Nürnbergu - 'liječničko suđenje'“, Liječničke novine, 177, ožujak 2019.

31. Varga, T., Szabó, A., Dósa, A., Bartha, F., „Criminal Liability Of Physicians And Other Health Care Professionals In Hungary (Review Of Case Law Between 19962000)“" Med Law (2006.) 25.

32. Vollmann, J., Winau, R., ,Informed consent in human experimentation before the Nuremberg Code“", British Medical Journal, 1996., 313:7070.

33. Zietsman, C. J., Medical Negligence In Ancient Legal Codes. Dostupno na: http:// akroterion.journals.ac.za.

34. Žarković Palijan, T., Kovač, M., Sarilar, M., Narić, S., „Etička načela u kliničkim ispitivanjima na forenzičko-psihijatrijskoj populaciji“, MEDIX, ožujak/travanj, 2012., god. XVi I i, 98/99.

35. Wapner, L., Aspects and functions of Professional Autonomy and Self-Regulation, EFMA Forum, Riga, 2013.

\section{Mrežni izvori}

1. https://www.britannica.com/biography/

2. www.starapovijest.eu/hamurabijev-zakonik/ 


\section{HISTORY OF LEGAL LIABILITY OF PHYSICIANS}

The regulation today of physician legal liability and also that of other healthcare workers cannot be understood without insight into the history of the development of that type of professional liability. The author shows the regulation of physician liability in legal documents from the Middle Ages, including Mesopotamian and Egyptian sources as well as documents from Ancient Greek and Roman Law. Also, the legal regulation of physician liability at law from the Middle Ages as well as development and liability after the French Revolution are shown. In particular, the terrible misuse of doctors and their responsibility for Nazi crimes are outlined. Finally, it is shown that in a modern society, a system of professional legal physician liability represents the middle road in between the two extremes.

Key words: physician liability, ancient documents, legal sources from Roman law, law from the Middle Ages, responsibility in the modern era 